\title{
Rediscovering our calling
}

Tensions between the profession and the academy have a long history. As Robert Maxwell recounts in this issue (p.55), arguments over the proper education of architects go back to at least the eighteenth century, while as Dean Hawkes asserts (p.35), the pitting of practitioners against educators overlooks the fact that design lies at the heart of what both do. This debate has arisen anew because of a common threat facing both the architectural profession and the schools: increasing marketplace pressures to do more in less time at lower costs and growing public scepticism of the professions.

This has happened before. In the early nineteenth century, particularly in the United States, popular sentiment arose against the professions as anti-democratic elites, causing many jurisdictions to repeal licensing laws. That, in turn, led professionals to form associations in an effort to reassert control over their practices and to reposition the professions as the stewards of public health, safety, and welfare. Professional education moved into the universities, and the professional associations exerted considerable influence over the curriculum, with many faculty drawn from current or former practitioners. Thus began the uneasy alliance between the profession and the academy.

That relationship has been particularly strained in the last decade with the rise of the global economy and the return of the free-market critique of the professions and the universities. Architects have faced growing time and monetary pressures and academics have felt a similar squeeze. These pressures will continue until we return to our primary role in attending to the public good. We have, for too long, acted like elites, enjoying the monopoly in the marketplace that licensure and tenure provides without an equal devotion to the public need, and so have eroded the real base of our support.

As we discuss the responsibilities of the schools and the profession to each other, we should also do some soul searching as to our true purpose. Without rediscovering our responsibilities to the public, our profession may eventually become indistinguishable from business, shorn of licensure, and our schools eventually drummed out by distance-learning companies, without a single tenured professor - at which point, there may be little worth debating. 


\section{architectural research quarterly}

\section{Subscribe now and save $20 \%$}

Innovative in conception, unique in breadth and generously illustrated, this pace-setting quarterly publication from Cambridge University Press links, on a global scale, the worlds of architectural practice and research. arq regularly includes extensive peer-reviewed sections on design, history, theory, construction, environmental design, information technology and practice - as well as structures, urbanism and documents. These are supplemented by letters, reports, reviews, a directory of specialist research centers and consultancies and an annual index. Each issue opens with a leader and closes with insight, a personal end-piece. In its three year history, arq has published work from all over the world: from Chile to Sweden and from Japan to the Netherlands - with a strong representation from the United Kingdom and United States. arq, like architecture itself, is all-embracing and written by and for both practitioners and academics. It provides an outlet for all those who wish to disseminate their work to an international audience.

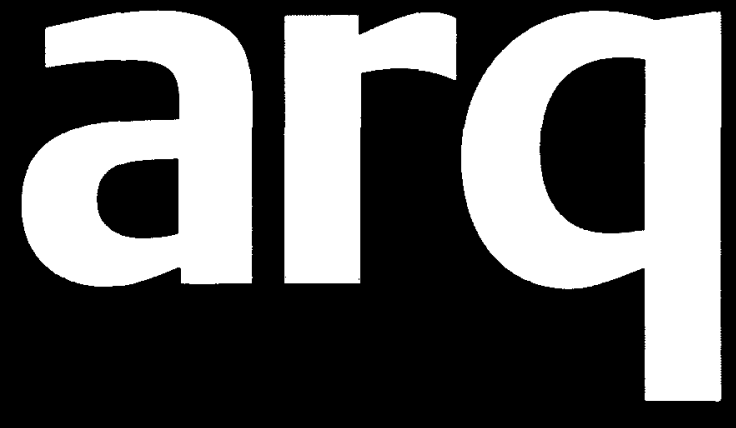

Please enter my subscription to arq: architectural research quarterly, volume 4, 2000

$\square$ E76 (normally $E_{95}$ ) institutions print only

$\square$ E22 (normally E28) students

$\square$ E44 (normally $E_{55}$ ) individuals print only

Eu residents only. VAT may be payable at your local rate if not registered.

OurVAT registration number: GB 214141614 If registered, your VAT registration no:

Total subscription payment $\mathrm{E}$

EU residents only, if not registered add VAT at appropriate rate

Total $\mathbf{E}$

Name

Address

Payment enclosed

Cheque in sterling (poyable to Cambridge University Press) Bank Draft

Post Office Giro (A/C no 5716055 CB Bootle - please send advice of payment) Credit Card - VISA | MasterCard | American Express (delete where applicable)

Card no

Expiry date

Signature

Photocopy this page and send your order to: Journals Customer Services, Cambridge University Press, Edinburgh Building, Shaftesbury Road, Cambridge, CB2 2RU

$T+44(0) 1223326070$

$F+44(0) 1223315052$

E journals_subscriptions@cup.cam.ac.uk 